\title{
Changes in root morphology of anchored water hyacinth Eichhornia azurea (Sw.) Kunth (Pontederiaceae) in a perennial bay of Pantanal, Brazil
}

\author{
Alterações na morfologia de camalote Eichhornia azurea (Sw.) Kunth \\ (Pontederiaceae) em uma baía perene do Pantanal, Brasil
}

\author{
Wagner Antonio Chiba de Castrol(*) \\ Paulo Francisco da Silva Campos Machado Zava \\ Stephani Dal Bem Demczuk ${ }^{3}$
}

\begin{abstract}
In this study it was evaluated changes in situ in root and leaves of Eicchornia azurea, an invasive macrophyte of worldwide reservoirs, in a gradient of organic matter provided by allochthonous and autochthonous sources at Medalba bay, Pantanal, Brazil. The results showed that the greater the distance of riparian vegetation and sediment, the greater length, dry weight of roots and lower the distance between their insertions. The leaves did not present dry weight differences in the gradient. It was conclude that these macrophytes optimize the root morphology to absorb nutrients along a gradient of organic matter.
\end{abstract}

Key words: E. azurea; aquatic macrophytes; phenotypic plasticity.

\section{Resumo}

Nós avaliamos alterações in situ em raízes e folhas de Eicchornia azurea, macrófita invasora de reservatórios no mundo todo, em um gradiente de matéria orgânica formado por fontes autóctones e alóctones na Baía da Medalha, Pantanal, Brasil. Quanto maior a distância da mata ripária e do sedimento, maior o comprimento, peso seco das raízes e menor a distância entre suas inserções. As folhas não apresentaram pesos secos diferentes ao longo do gradiente. Provavelmente estas

\footnotetext{
I Dr.; Biólogo; Professor Adjunto da Universidade Federal da Integração Latino-Americana, UNILA; Endereço: Avenida Sílvio Américo Sasdelli, Vila Residencial A, CEP: 85866-000, Foz do Iguaçu, Paraná, Brasil; E-mail: wagner.castro@unila.edu.br (Autor para correspondência).

2 MSc.; Biólogo; Integrante de Projeto de Pesquisa do Laboratório de Ecologia Funcional, Departamento de Ecologia, Instituto de Ciências Biológicas da Universidade Federal de Goiás; Endereço: Campos Samambaia, CEP: 7400 I-970, Goiânia, Goiás, Brasil; E-mail: vladwosttock@hotmail.com

3 MSc.; Biólogo; Integrante do Centro de Ciências Biológicas de da Saúde da Universidade Federal de Mato Grosso do Sul; Endereço: Cidade Universtária s/nº, CEP:79070-900, Campo Grande, Mato Grosso do Sul, Brasil; E-mail: stephanidbd@gmail.com
} 
macrófitas otimizam a morfologia das suas raízes para absorção de nutrientes ao longo de um gradiente de matéria orgânica.

Palavras-chave: E. azurea; macrófitas aquáticas; plasticidade fenotípica.

\section{Introduction}

In lentics environments, the main autochthonous sources of nutrients are the detritus (generated by decomposition processes) and sediment; alochtonous are provided by lotic effluents (i.e. rivers, streams) and organic matter by riparian and leaching processes (TUNDISI; MATSUMURATUNDISI, 2008). So there is a complex dynamic involving different nutrient source, with intrinsic and extrinsic availability as well as organisms utilizing these resources (BARNES, MANN 1991).

The lentic coastal zones are considered an ecotone between terrestrial vegetation and pelagic zone (JORGENSEN, 1980). It's the main biological metabolic zone in aquatic systems, due high interaction between sediment and water column, nutrient contribution provided by riparian and high incidence of aquatic macrophytes (WETZEL, 2001). Aquatic macrophytes are the most important organisms of nutrient dynamics in shallow lentics (WETZEL, 2001). Due to huge biomass, macrophytes detritus are the main autochthonous nutrient sources in these systems (PIECZYNSKA, 1993).

In floating macrophytes, the roots are the first via of nutrient assimilation (i.e. nitrogen and phosphate). These nutrients are mainly provided by the nutritional gradient between water column and sediment (BRISTOW; WHITCOMBE 1971). The roots development and operation are affected by these nutritional gradients (HAUSER et al., 1995; LYNCH, 1995). Consequently, these nutritional gradient influences the plant ramets size, number of leaves, and root complexity, as well as its ability to exploit and acquire resources (DONG; DE KROON, 1994). There are not studies involving changes in macrophytes in different nutritional gradients at Pantanal region, which represents the larger wetland in the world, with an outstanding seasonality due to overflow fluxes (SILVA; ABDON, 1998).

Water hyacinth (Eichhornia azurea (Sw.) Kunth, Pontederiaceae) is one of the main native aquatic plants in Pantanal. It's perennial, with floating rhizomes and anchored at the surrounding substrate (POTT; POTT, 2000). Weevaluate in situ morphological root and leaves parameters of E. azurea in an environmental gradient of organic matter. We hypothesized that as higher the riparian distance and a most deep water column (i.e. farthest from the main alochtonous and autocthonous organic matter fonts), increases the root structural complexity.

\section{Material and Methods}

Pantanal, the largest wetlands in the world $\left(160,000 \mathrm{~km}^{2}\right)$, comprises an extensive alluvial plain along the central region of South America, with numerous perennial and ephemeral lagoons (CUNHA; FISHER, 2009). The meandric lagoons of Pantanal, with depth ranging from a few centimeters to $2 \mathrm{~m}$, are regionally called bays and often covered by aquatic plants 
(PRANCE; SCHALLER, 1982). Our study was conducted in a meandric lagoon called Medal bay (UTM 498,7835; 4.3 ha in area) (CARVALHO et al., 2003), located in the sub-region of the Miranda and Abobral Pantanal (SILVA; ABDON, 1998) during dry season (October). This perennial bay flooded annually by the Miranda river, has a great amount of organic matter and clay sediment. The Medal bay presents dense riparian and an E. azurea population, arranged like a belt, around all the edge of the lagoon. In dry season, the main allochthonous nutrient source is particulate organic matter from the riparian; the sediment and macrophyte debris are the main autochthonous nutrient sources.

We divide the E. azurea belt in three sampling zones, according the distance with the riparian and size of water column: (a) between 1 to $5 \mathrm{~m}$ distance from the riparian and between 0.3 to $0.5 \mathrm{~m}$ water column deep, (b) between 10 to $15 \mathrm{~m}$ distance from the riparian and between 0.8 to $1.0 \mathrm{~m}$ water column deep, (c) $>20 \mathrm{~m}$ distance from the riparian and between 1.5 to $1.8 \mathrm{~m}$ water column deep. In each sampling zone, we collected 30 ramet fragments, totalizing 90 ramet fragments. A ramet fragment was considered as a ramet with flowers and three nodes, in which inserted three leaves and three roots. We measured the distance among the root insertions and the root length. After $48 \mathrm{~h}$ drying $\left(60^{\circ} \mathrm{C} \pm 5\right)$, we weighted the roots and leaves. To standardize the ramets age at the different sampling zones, we collected mature reproductively ramets (i.e. flower presence) and leaves with the same size.

We considered a sampling unit as the average value of three randomized ramets of the same sampling zone ( $a, b$ and $c)$, totalizing 30 sampling units. To visualize the differences among root parameters of different riparian zones, we used a Principal Component Analysis and dispersion graphics. All analyses were performed by the software PAST, v.2.11 (HAMMER et al., 2001). To verify significant differences between sampling zones, we applied Mann-Whitney pairwise and Bonferroni correlation test with 0.01 of significance according Shapiro-Wilk normality test (ZAR, 1999).

\section{Results and Discussion}

The leaves did not differed significantly comparing the three sampling zones $(\mathrm{F}=$ 1.031, $P=0.3702)$. The parameters used in the roots description (PCA components, Figure 1) had good explanation on the distribution of the samplings (89.24\%). Roots structures showed a gradient according the distance from the riparian (Figure 2). As far as the distance of the riparian, macrophytes presented higher roots length and dry weight as well as shorter distances between the root insertions (Figure 1 and Figure 2). The ramets closer to riparian (a) presented differences between the farthest ramets (c) for all parameters evaluated (Table 1). The intermediate position ramets (b), presents differences between the farthest ramets (3) for roots insertion distances and root dry weight, but didn't present differences between closer ramets (a). About the root length, the intermediate ramets (b) present differences between closer ramets (a), however presented no differences between farthest ramets (c).

In this study we attempted to standardize the age of ramets and intraspecific competition in different sampling zones, important variables in studies involving population (GATSUK et al., 1980; MONY et 
Figure 1 - Principal Component Analysis (PCA) and the distance between the root insertions, root length and root dry weight of Eichhornia azurea in different sample zones

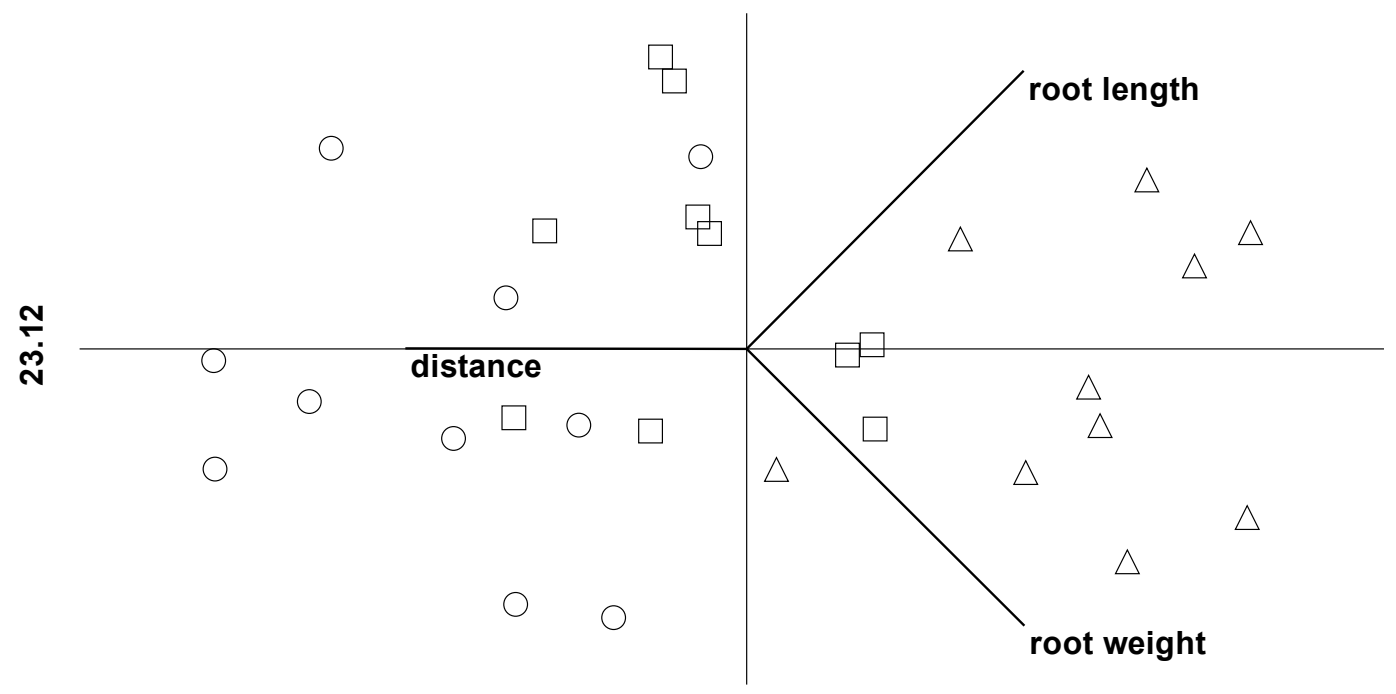

Source: Castro,W.A. C. et al. (2015).

Note: $\bigcirc=$ Samples collected among $1-5 \mathrm{~m}$ from the riparian and $0.3-0.5 \mathrm{~m}$ of water column; $\square=$ among $10-15 \mathrm{~m}$ from the riparian and $0.8-1 \mathrm{~m}$ water column and $\Delta=$ more than $20 \mathrm{~m}$ from the riparian and among I.5- $1.8 \mathrm{~m}$ water column.

al.,2007). For aquatic macrophytes, different developmental stages presents differential development of vegetative structures (CARR et al., 1997). Thus, we standardized the collection method exploiting mature ramets (presence of flowers) to standardize its age. The lack of differences about dry weight of leaves indicates the same photosynthetic potential (DICKERMAN et al., 1986) of different sampling zones ramets. According Tundisi and Matsumura-Tundisi (2008), as closer the riparian vegetation and lower water column, higher nutrient availability. So the only variable controlling these macrophytes root development was the gradient of organic matter, provided by the relationship between the riparian (allochthonous source) and sediment (autochthonous source).
The availability of nutrients affects not only the biomass, but the ramet morphology as a whole (PIQUERAS et al., 1999), mainly the length of stolons (CAIN, 1994), and branching frequency (DONG; DE KROON, 1994). However, the main root structural changes are related to the morphological plasticity of structures for resource acquisition (DE KROON; HUTCHINGS, 1995). When nutrient availability decreased, the root architecture changed to optimize nutrient absorption. The roots become larger, both in length and mass, in order to increase the exposure for nutrient assimilation. The distance between root insertions decreases, suggesting a higher density and therefore higher number of roots per stolon. 
Figure 2 - Boxplot with root parameters and leaves of Eichhornia azurea (A) between 1 and $5 \mathrm{~m}$ from the riparian and $0.5 \mathrm{~m}$ water column, (B) between 10 and $15 \mathrm{~m}$ from the riparian and $1 \mathrm{~m}$ water column and $(\mathrm{C})$ more than $20 \mathrm{~m}$ from the riparian and more than $1.5 \mathrm{~m}$ water column
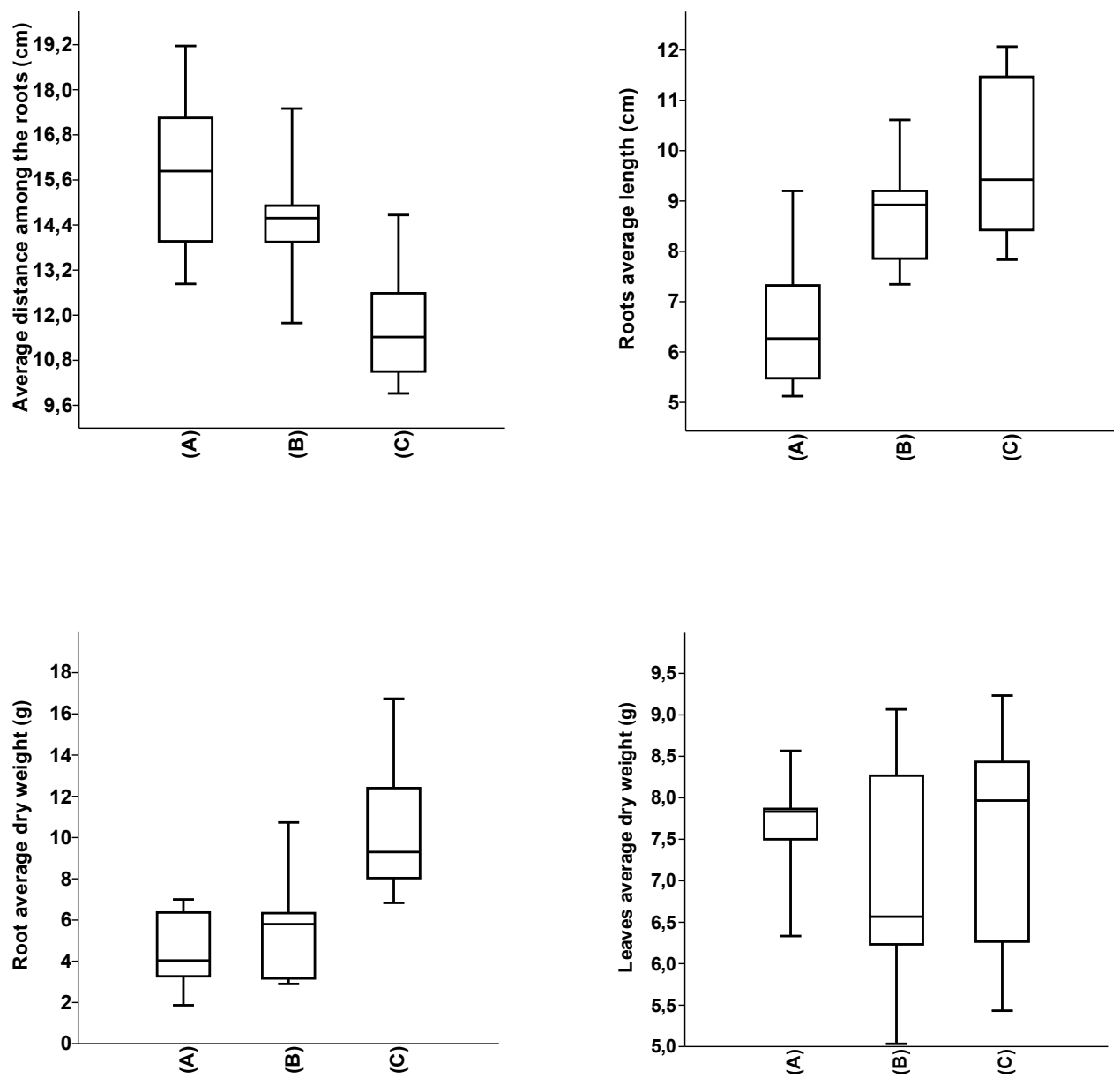

Source: Castro,W.A. C. et al. (20/5).

Table 1 - Significances ( $P$ values) of a Mann - Whitney test with Bonferroni correction comparing root architecture parameters of Eichhornia azurea for different riparian distances (Rd)

\begin{tabular}{lcccccccc|}
\hline & \multicolumn{2}{c}{$\begin{array}{c}\text { Distance among } \\
\text { insertions }\end{array}$} & & \multicolumn{2}{c|}{ Root length } & & \multicolumn{2}{c|}{ Dry weight } \\
\cline { 2 - 3 } \cline { 8 - 9 } & $10-15 \mathrm{~m}$ & $>20 \mathrm{~m}$ & & $10-15 \mathrm{~m}$ & $>20 \mathrm{~m}$ & & $10-15 \mathrm{~m}$ & $>20 \mathrm{~m}$ \\
\hline $1-5 \mathrm{~m}$ & 0.2896 & 0.0015 & & 0.0019 & $<0.0001$ & & 0.7336 & 0.0002 \\
$10-15 \mathrm{~m}$ & - & 0.004 & & - & 0.1041 & & - & 0.0017 \\
\hline
\end{tabular}

Source: Castro,W.A. C. et al. (20I5). 


\section{Final Considerations}

Eicchornia. azurea has been considered a problem in reservoirs in Brazil (FERNANDEZ et al., 1993). Its growth is enhanced by eutrophication (THOMAZ, BINI, 1998). The mechanical and chemical control of this species is often inefficient and expensive (TSNSW, 2009) as well as the use of biological control, with limited success (CARAUTA et al., 1991). The biology of other species ofthe same genus Eicchornia crassipes (Mart.) Solms (Pontederiaceae) is already well studied, but more studies are needed to understand the development of E. azurea, particularly as the morphological plasticity in situ. These mechanistic studies are important to understand the invasion processes to foment its efficient management.

\section{Acknowledges}

We thanks "Curso de Campo Ecologia do Pantanal”, by UFMS for financing the collection and physical structure available and "Prof. Dr. Sidinei Magela Thomaz" for suggestions that improved the quality of our work.

\section{References}

BARNES, R. S. K.; MANN, K. H. Fundamentals of Aquatic Ecology. Oxford: Blackwell Sci., 1991.

BRISTOW,J.M.; WHITCOMBE, M. The role of roots in the nutrition of aquatic vascular plants. American Journal of Botany, v.58, p.8-13, 1971.

CARAUTA,J.P.P.; ROMERO, S.H.F.; FRIGOLETTO,M.F.; BOSÍSIO, B. Conservação da flora na região dos reservatórios de Santana e Vigário, Rio de Janeiro. Albertoa, v.3, n.8, p.61-77, 1991.

CARR, G. M.; DUTHIE, H. C.; TAYLOR, W. D. Models of aquatic plant productivity: a review of the factors that influence growth. Aquatic Botany, v.59, p.195-215, 1997.

CARVALHO, L. N.; DEL-CLARO, K.; TAKEMOTO, R. M. Host-parasite interaction between branchiurans (Crustacea: Argulidae) and piranhas (Osteichthyes: Serrasalminae) in the Pantanal wetland of Brazil. Environmental Biology of Fishes, v.67, p.289-296, 2003.

CAIN, M. L. Consequences of foraging in clonal plant species. Ecology, v.75, p.933-944, 1994.

CUNHA, N. L.; FISCHER, E. Breeding system of tristylous Eichhornia azurea (Pontederiaceae) in the southern Pantanal, Brazil. Plant Systematics and Evolution, v.280, p.53-58, 2009.

DE KROON, H.; HUTCHINGS, M. J. Morphological plasticity in clonal plants - the foraging concept reconsidered. Journal of Ecology, v.83, p.143-152, 1995. 
DICKERMAN, J. A.; STEWART, A. J.; WETZEL, R. G. Estimates of net annual aboveground production: sensitivity to sampling frequency. Ecology, v.67, n.3, p.650-659, 1986.

DONG, M.; DE KROON, H.Plasticity in morphology and biomass allocation in Cynodon dactylon, a grass species forming stolons and rhizomes. Oikos, v.70, p.99-106, 1994.

FERNÁNDEZ, O. A.; SUTTON, D. L.; LALLANA, V. H.; SABBATINI, M. R.; IRIGOYEN, J. Aquatic weed problems and management in South and Central America. In: PIETERSE, A. H.; MURPHY, K. J. (Ed.). Aquatic weeds: the ecology and management of nuisance aquatic vegetation. Oxford: Oxford University Press, 1993.

GATSUK, E.; SMIRNOVA, O.; VORONTZOVA, L. I.; ZAUGOLNOVA, L. B.; ZHUKOVA, L. A. Age states of plants of various growth forms: a review.Journal of Ecology, v.68, p.675-696, 1980.

HAMMER, Ø.; HARPER, D. A. T.; RYAN, P.D.PAST: Paleontological statistics software package for education and data analysis. Palaeo ElectR, v.4, n.1, p.1-9, 2001.

HAUSER, M. T.; MORIKAMI, A.; BENFEY, P. N. Conditional root expansion mutants of Arabidopsis. Development, v.121; p.1237-1252, 1995.

JORGENSEN, S. E. Water development, supply and management. Oxford: Lake Management, Pergamon Press, 1980. (v.14).

LYNCH,J. Root architecture and plant productivity. Plant Physiology, v.109, p.7-13, 1995.

MONY,C.; KOSCHNICK, T.J.; HALLER,W.T.; MULLER, S. Competition between two invasive Hydrocharitaceae (Hydrilla verticillata L. f. and Egeria densa (Planch)) as influenced by sediment fertility and season. Aquatic Botany, v.86, p.236-242, 2007.

PIECZYNSKA, E. Detritus and nutrient dynamics in the shore zone of lakes: a review. Hydrobiology, v.251, p.49-58, 1993.

PIQUERAS,J.; KLIMES, L.; REDBO-TORSTENSSON,P.Modelling the morphological response to nutrient availability in the clonal plant Trientalis europaea L. Plant Ecology, v.141, p.117-127, 1999.

POTT, A.; POTT, V. J. Plantas Aquáticas do Pantanal. Brasília, DF: Embrapa, 2000.

PRANCE, G. T.; SCHALLER, G. B. Preliminary study of some vegetation types of the Pantanal, Mato Grosso, Brazil. Brittonia, v.34, p.228-251, 1982.

SILVA, J. S. V.; ABDON, M. M. Delimitação do Pantanal Brasileiro e suas sub-regiões. Pesquisa Agropecuária Brasileira, v.33, p.1703-1711, 1998.

THOMAZ, S. M.; BINI, L.M. Ecologia e manejo de macrófitas aquáticas em reservatórios. Acta Limnologica Brasiliensia, v.10, n.1, p.103-116, 1998. 
TSNSW (THE STATE OF NEW SOUTH WALES) - Noxious weed declarations: Anchored water hyacinth. New South Wales, Australia: Department of Primary Industries. 2009. Disponível em: <http://www.dpi.nsw.gov.au/content/agriculture/pests-weeds/weeds>. Acesso: em $11 \mathrm{dez} .2012$.

TUNDISI,J.G.;MATSUMURA-TUNDISI,T.Limnologia. São Paulo: Oficina de textos, 2008.

WETZEL, R. G. Limnology: Lake and River ecosystems. Philadelphia: Academic Press, 2001.

ZAR, J. H. Biostatistical analysis. 4. ed. Upper Saddle River: Prentice Hall, 1999. 